Reprinted from the Journal of Environmental Quality

Volume 27, no. 6, Nov.-Dec. 1998, Copyright (C) 1998, ASA, CSSA, SSSA

677 South Segoe Rd., Madison, WI 53711 USA

\title{
Boron, Zinc, Iron, and Manganese Content in Four Grassland Species
}

\author{
M. J. Adarve, A. J. Hernández, A. Gil, and J. Pastor*
}

\begin{abstract}
A pot experiment was carried out to test the response of the $B$, $\mathrm{Zn}, \mathrm{Fe}$, and $\mathrm{Mn}$ concentration in four wild herbaceous species exposed to three landfill leachate treatments of increasing concentration of contaminants. The species tested were clustered clover (Trifolium glomeratum L.), cotton clover (T. tomentosum L.), wall barley (Hordeum murinum L.), and soft brome (Bromus hordaceus L.). The legume species accumulated more $F e$ and $B$ than the grasses. The least contaminated leachate (leachate $A$ ) significantly increased the Fe and Mn content in $T$. glomeratum. Leachate B significantly increased the $\mathrm{Zn}$ content in both clover species and Fe content in $T$. glomeratum and $\boldsymbol{H}$. murinum, while it significantly decreased the B content in $T$. glomeratum. The most contaminated leachate (leachate C) significantly increased the $\mathrm{Zn}$ content in $T$. glomeratum, while it significantly decreased the $B$ and Fe content. In the four species the content of $B, F e$, and $M n$ in the plants under the leachate treatments was in a normal values range, while in $\boldsymbol{T}$. glomeratum and $\boldsymbol{H}$. murinum the $\mathrm{Zn}$ content had in some cases a toxic level $\left(>100 \mathrm{mg} \mathrm{L}^{-1}\right)$. The dry weight of the four species tested diminished significantly under the most contaminated leachate. The ANOVA confirmed a major significant influence of the "species factor" on the response of the plant to leachate supply, but the treatment factor also had significant $F$-values in some cases. The species tested have a potential revegetation value for some areas degraded by landfill leachates.
\end{abstract}

M.J. Adarve and A.J. Hernández, Campus Universitario, Edidficio de Ciencias, Ecologia, Univ. de Alcala de Henares, Carretera MadridBarcelona, Km 33.600, 28871 Alcala de Henares, Madrid, Spain; and A. Gil and J. Pastor, Environmental Sciences Research Center, CSIC Serrano, 115, 28006, Madrid, Spain. Received 31 July 1997. *Corresponding author (ebvpp64@fresno.csic.es).

Published in J. Environ. Qual. 27:1286-1293 (1998).
THE relationship of trace elements, such as $\mathrm{Mn}, \mathrm{Fe}$, 1 and $\mathrm{Zn}$, with problems of soil fertility and plant nutrition has been studied extensively. However, since the 1990s the focus has been on potential toxicity with the increase in industrial activity, the excessive use of fertilizers and pesticides, the application of sewage sludge as well as waste disposal on land and in mines.

Landfills used for the disposal of municipal solid wastes often generate leachate. Without proper collection and treatment, surface water, groundwater, and the surrounding soil may become polluted by these wastes having potentially negative effects on the biota (Lozidou and Kapetanios, 1991; Christensen et al., 1992; Adarve and Rebollo, 1993; Adarve et al., 1994, 1995; Pastor et al., 1993a, b; Hernández et al., 1998). Leachates from landfills contain large amounts of many plant nutrients, especially macronutrients, such as $\mathrm{N}, \mathrm{Ca}, \mathrm{K}$, or $\mathrm{Mg}$, but today there is a controversy about their use as fertilizers because of the presence of potentially harmful trace elements.

Recycling these leachates may beneficially reuse plant nutrients and organic matter of these wastes and may be fertilizer for biomass production (Bramryd, 1988; Gordon et al., 1989; Cureton et al., 1991). However, there are certain risks involved in their use, since leachates may contain heavy metals in varying concentrations that might be harmful to plants. In recent years, trace metal accumulation in plants has been a serious

Abbreviations: CEC, cation exchange capacity; TDS, total dissolved solids; COD, chemical oxygen demand; ANOVA, analyses of variance. 
environmental concern, primarily because their uptake from contaminated soils is the principal process by which trace metals enter the food chain. Thus, more information about the destiny of heavy metals in landfill leachates is needed to design land application programs with minimal environmental impact.

A factor determining plant uptake of heavy metals may be their availability in the soil. The availability will depend on their chemical speciation and is determined by the physical and chemical properties of the soil, such as soil texture, organic matter content salinity, cation exchange capacity, $\mathrm{pH}$ and redox potential (Otte et al., 1993). Among these factors, soil $\mathrm{pH}$ is the most important (Shuman 1986; Lorenz et al., 1994), but clay content, ion interaction, and organic matter content are also significant (Lorenz et al., 1994; Moreno et al., 1996). In addition, heavy metal availability can be directly affected by the plant itself (Zhang et al., 1991; Moreno et al., 1996).

The purpose of this study was to determine the tolerance of wild herbaceous species to landfill leachates with varying levels of contamination by means of plant concentrations of $\mathrm{B}, \mathrm{Zn}, \mathrm{Fe}$, and $\mathrm{Mn}$, and growth. The study was conducted under controlled environmental conditions. Greenhouse experiments were conducted using four representative species that grow both on municipal landfill sites and Mediterranean grasslands. Dry weight of the aerial plant parts was observed at harvest to indicate plant tolerance to leachates.

\section{MATERIALS AND METHODS}

\section{Greenhouse Study}

A pot experiment under greenhouse conditions was designed to study trace element concentration in wild herbaceous species to leachate exposure. The species tested included two clovers ( $T$. glomeratum $\mathrm{L}$. and $T$. tomentosum $\mathrm{L}$.) and two grasses $(H$. murinum $\mathrm{L}$. and Bromus hordaceus $\mathrm{L}$.). Three leachates with varying concentrations were applied to the soils and plants. The experimental design consisted of $4 \times 4 \times 4$ factorial (four species, four solutions, and four replications) for a total of 64 pots.

The pots were filled with $3 \mathrm{~kg}$ of soil collected in the study area and sieved through a $2 \mathrm{~mm}$ mesh screen. Several seeds of the four species were germinated for $7 \mathrm{~d}$ in darkness at about $25^{\circ} \mathrm{C}$ on filter paper permanently saturated with deionized water inside Petri dishes. After $7 \mathrm{~d}$, five seedlings per pot were transplanted in a total of 16 pots per species. Four pots were controls and another four were used for each of the three leachate treatments. The treatments began after $21 \mathrm{~d}$ of plant growth in the pots. The leachates were applied as the water supply of the corresponding plants, while the control pots received an equivalent amount of deionized water. Thus, of the 16 pots with $T$. glomeratum, four pots were watered with deionized water (control pots), four pots were watered with leachate $\mathrm{A}$, four pots with leachate $\mathrm{B}$ and four with leachate $\mathrm{C}$, and the same for the rest of species. The leachate effects on the plants and the chemical characteristics of the soil were measured at harvest.

The experiment took place in the greenhouse from March to June. The plants were grown in the sunlight with a natural photoperiod of 12 to $15 \mathrm{~h} / \mathrm{d}$ and watered with $50 \mathrm{~mL} /(\mathrm{d} / \mathrm{pot})$ of deionized water (for controls not exposed to leachates) or with a similar quantity of different landfill leachates (for the
Table 1. Selected physical and chemical properties of the soils used in the greenhouse experiment.

\begin{tabular}{lc}
\multicolumn{1}{c}{$\begin{array}{c}\text { Soil } \\
\text { parameters }\end{array}$} & $\begin{array}{c}\text { Soil } \\
\text { content }\end{array}$ \\
\hline Fine gravel, \% & 3 \\
$<\mathbf{2}$ mm fraction, \% & 97 \\
Sand, \% & 49 \\
Clay, \% & 38 \\
Silt, \% & 13 \\
Texture & Loam \\
pH & 7.1 \\
Conductivity, Sm & -1 \\
Organic matter, \% & 1430.0 \\
CEC, cmol/Kg & 5.0 \\
\hline
\end{tabular}

corresponding plants). The air temperature values in the greenhouse were very similar with a mean of $23.8^{\circ} \mathrm{C}$. The mean air temperature ranged from 24.2 to $23.5^{\circ} \mathrm{C}$ with a maximum of $31.5^{\circ} \mathrm{C}$ and a minimum of $18.5^{\circ} \mathrm{C}$. With a mean of $74 \%$ the relative humidity values were also very similar. The maximum and minimum mean values were 80 and $69 \%$, respectively, and the maximum and minimum extreme values were 87 and $58 \%$, respectively.

\section{Leachate and Soil Sources}

The leachates chosen were taken from three landfills previously characterized (Hernández et al., 1998) and are representative of urban residue contamination in central Spain. Two of the three leachates (A and B) were collected from piezometers in subterranean discharge areas located at the bottom of sealed urban waste landfills. These landfills are situated near water courses fed by local groundwater, or correspond to leachates diluted by the subsurface water. Most of the year the groundwater level in these subterranean discharge areas is very close of the topographical surface. Thus, these leachates are a combination of those from landfills and groundwater. They were chosen due to the importance of their ecotoxicological impact on the soils and plants that grow in wet areas located at the foot of the landfills, which are frequently used as pastures for sheep (Ovis sp.). The other more contaminated leachate (C) was collected from a well built to receive leachates from a sanitary landfill. The collected leachate was kept in storage at $4^{\circ} \mathrm{C}$.

The soil used was an Alfisol (USDA, 1990) on a fluvial breccia conglomerate. This is a frequent and representative soil type in central Spain, where several landfills are situated. The bulk soil samples were taken from the top $15 \mathrm{~cm}$. The percentage of fine gravel in the soil was $3 \%$, and $97 \%$ belonged to the $<2 \mathrm{~mm}$ fraction. The soil was sieved with a $2 \mathrm{~mm}$ mesh screen. Its texture was loam with a percentage of sand, clay, and silt of 49,38 , and $13 \%$, respectively (Table 1 ). The soil $\mathrm{pH}$ was 7.1 which is common in many Mediterranean soils. The soil used was, in general, finely textured material with appreciable conductivity, cation exchange capacity (CEC) and organic matter content (Table 1). The physical and chemical properties analyzed in this soil (such as texture, clay content, $\mathrm{pH}$, organic matter, or CEC) were those frequently reported as being of special interest to the availability and uptake of metals to plants (Lorenz et al., 1994; Tack et al., 1996; Moreno et al., 1996).

\section{Selection and Plant Measurements}

These wild species were chosen in view of their natural frequency in the landfill plant cover, in the subterranean discharge area at the foot of several landfills in the study area and surrounding natural pasture areas not affected by landfill leachates. 
Three of the selected species ( $T$. glomeratum, $T$. tomentosum, and $B$. hordaceus) have a food value for sheep and some wild animal species (especially rabbits, Oryctolagus cuniculus L.) and the fourth (H. murinum) is a representative ruderal species in this environment. The legume species were selected for their importance in the revegetation of degraded soils of these landfills (Pastor et al., 1993c). The seeds were collected from natural grasslands in the surrounding area.

At harvest the trace element concentrations in the aerial plant part and the dry weight were measured in 4-mo-old plants, that is, in their flower phenological stage. The plants were also observed for foliar injury at harvest. The dry weight was measured in each individual plant. The chemical analyses were performed in the soil and all plants from each pot.

\section{Chemical Analysis}

Parameters analyzed in leachates included: $\mathrm{pH}$, conductivity, total dissolved solids (TDS), chemical oxygen demand (COD), total hardness, $\mathrm{Cl}^{-}, \mathrm{SO}_{4}^{-}, \mathrm{NO}_{3}^{-}, \mathrm{CO}_{3}^{=}, \mathrm{HCO}_{3}^{-}, \mathrm{F}, \mathrm{PO}_{4}$, $\mathrm{Ca}, \mathrm{Mg}, \mathrm{Na}, \mathrm{K}, \mathrm{NH}_{4}^{+}, \mathrm{B}, \mathrm{Fe}, \mathrm{Cu}, \mathrm{Zn}$, and $\mathrm{Mn}$. In the soil samples, $\mathrm{pH}$, conductivity, organic matter and CEC were determined. In the aerial plant parts, B, Zn, Fe, and Mn were analyzed.

Prior to analyses, the soils were air dried at room temperature for several days. The soil was extracted for cation determination with a saturation method including $1 \mathrm{~N}$ ammonium acetate solution (Hernández and Pastor, 1989). The $\mathrm{pH}$ and conductivity were measured in a saturated paste. Clay was determined by the Bouyoucos method (Kilmer and Alexander, 1949).

Prior to the cation determination in the aerial plant parts, the plant material was washed sufficiently with deionized water and dried in a forced hot air heater at $80^{\circ} \mathrm{C}$ for $24 \mathrm{~h}$. The samples were weighed, ground in a mill (model "culatti", with $1 \mathrm{~mm}$ mesh screen) and later subjected to an organic mineralization process to dissolve the mineral components. The mineralization process consisted of adding cold concentrated nitric acid and standing for $5 \mathrm{~h}$, followed by heating to $100^{\circ} \mathrm{C}$. After that, perchloric acid was added and the temperature increased to $200^{\circ} \mathrm{C}$ (Isaac and Kerber, 1971).

The leachates, plants, and soils were analyzed following the official Spanish methods (Ministerio de Agricultura, Pesca y Alimentación, 1982). The analytical procedures and details of extractions for soils and plants were those described by Hernández and Pastor (1989). The anion concentrations of $\mathrm{Cl}^{-}, \mathrm{SO}_{4}^{=}, \mathrm{NO}_{3}^{-}, \mathrm{F}^{-}$, and $\mathrm{PO}_{4}^{=}$in leachates were analyzed by ion chromatography with a Dionex Model 10 chromatograph, using an AGHA precolum, an AS4A separator column and an AHMS suppressor column, connected to a recorder and a Hewlett-Packard 3390 A integrator. The chemical oxygen demand in leachates was determined by their permanganate oxidation capacity. The $\mathrm{CO}_{3}^{=}$and $\mathrm{HCO}_{3}^{-}$were determined with titration techniques. The $\mathrm{Ca}, \mathrm{K}$, and $\mathrm{Na}$ concentrations in the leachates and soils were determined by flame photometry and those of $\mathrm{Mg}, \mathrm{Fe}, \mathrm{Cu}, \mathrm{Mn}, \mathrm{Zn}$, and $\mathrm{B}$ in the leachates, soils, or plants by atomic absorption spectroscopy. The organic matter in the soils was determined by oxidation with potassium dichromate and concentrated sulphuric acid. The CEC in the soils was calculated by the sum of the total cation content analyzed.

\section{Data Analysis}

Several factorial analyses of variance (ANOVA) were carried out with the chemical variables of the soils as well as with the trace element concentration and dry weight of the plants.
The values of the control sample were compared with those from treated soil and plant samples. The computer program used was the P2V, Analysis of Variance and Covariance including Repeated Measures (BMDP Statistical Software package, 1993). The ANOVA of the soil data was achieved with one grouping factor (treatment). At the same time, a factorial ANOVA was carried out separately for each of the four species with one grouping factor (treatment). In addition, another ANOVA covered the concentration dry weight of all the plant species with two grouping factors (species and treatments).

\section{RESULTS AND DISCUSSION \\ Chemical Composition of the Leachates}

Leachate A was the least contaminated and leachate $\mathrm{C}$ the most contaminated leachate (Table 2). Leachate $\mathrm{C}$, in general, had higher concentrations of the parameters because it was specifically collected from a well, while the other two were collected from a combination of leachates from landfills and groundwater. In addition, the age of the landfill from which leachate $\mathrm{C}$ was collected was younger than that of the other two landfills from which leachates A and B were collected and was still in operation. The age of the last two landfills was approximately the same $(6 \mathrm{yr})$, but their respective groundwater geochemistry was vastly different. Therefore, between them there were some important differences with regard to wastewater chemistry, which will be described.

The concentrations in the leachates are in the range of levels most frequently reported for leachates and groundwater contaminated by landfill leachates (Cyr et al., 1987; Clark and Piskin, 1977; Loizidou and Kapetanios, 1991; Christensen et al., 1992).

The $\mathrm{pH}$ values of all leachates were basic (8.0-9.1).

Table 2. Chemical analysis of the leachates and typical leachate levels reported in literature.

\begin{tabular}{|c|c|c|c|c|}
\hline Leachate constituents & $\begin{array}{c}\text { Leachate } \\
\text { A } \\
\end{array}$ & $\begin{array}{c}\text { Leachate } \\
\text { B } \\
\end{array}$ & $\begin{array}{c}\text { Leachate } \\
\text { C }\end{array}$ & $\begin{array}{c}\text { Leachate levels } \\
\text { in literature } †\end{array}$ \\
\hline $\begin{array}{l}\text { pH } \\
\text { Conductivity, } \mathrm{Sm}^{-1} \\
\text { COD, } \mathrm{mg} \mathrm{L}^{-1} \mathrm{O}_{2} \ddagger\end{array}$ & $\begin{array}{c}8.3 \\
0.45 \\
120.0\end{array}$ & $\begin{array}{c}8.0 \\
1.61 \\
176.0\end{array}$ & $\begin{array}{r}9.1 \\
3.00 \\
1140.0\end{array}$ & $\begin{array}{l}3.7-8.5 \\
0.3-1.5 \\
60-1268\end{array}$ \\
\hline $\begin{array}{l}\text { TDS } \\
\text { Total hardness } \\
\mathrm{CI}^{-} \\
\mathrm{SO}_{4}^{-} \\
\mathrm{NO}_{3}^{-} \\
\mathrm{CO}_{3}^{=} \\
\mathrm{HCO}_{3}^{-} \\
\mathrm{PO}_{4}^{-} \\
\mathrm{F}^{-} \\
\mathrm{Ca}^{-} \\
\mathrm{Mg}^{-} \\
\mathrm{K} \\
\mathrm{Na} \\
\mathrm{NH}_{4}^{+} \\
\mathrm{B} \\
\mathrm{Zn}^{\mathbf{F e}} \\
\mathrm{Mn} \\
\mathrm{Cu}\end{array}$ & $\begin{array}{r}3977.0 \\
748.0 \\
983.0 \\
315.0 \\
10.0 \\
0.0 \\
1618.0 \\
0.0 \\
0.0 \\
215.0 \\
60.0 \\
82.0 \\
530.0 \\
168.0 \\
0.93 \\
0.08 \\
<0.00 \\
5.30 \\
<0.00\end{array}$ & $\begin{array}{r}18240.0 \\
909.0 \\
1928.0 \\
\mathbf{8} 924.0 \\
82.0 \\
122.0 \\
2116.0 \\
0.0 \\
0.0 \\
780.0 \\
2040.0 \\
70.0 \\
2075.0 \\
99.4 \\
1.96 \\
0.10 \\
0.10 \\
1.50 \\
<0.00 \\
\end{array}$ & 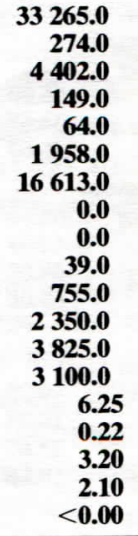 & $\begin{array}{c}3000-20000 \\
100-13370 \\
5-4350 \\
0-84000 \\
2-14.6 \\
-\S \\
- \\
0-50 \\
- \\
5-7000 \\
2-15000 \\
2-4000 \\
0-8000 \\
37-131 \\
1-70 \\
0-1000 \\
0-5000 \\
0-1500 \\
0-10\end{array}$ \\
\hline
\end{tabular}

† Clark and Piskin, 1977; Kmet and McGinley, 1982; Stegman, 1982; Sridheran and Didier, 1988; Bramryd, 1988; Gordon et al., 1989; Loizidiu and Kapetanios, 1991.

$\ddagger$ COD $=$ chemical oxygen demand; TDS $=$ total dissolved solids.

$\S$ - Undetermined. 
The $\mathrm{pH}$ and TDS values in the leachate $\mathrm{C}$ exceeded the commonly reported ranges in the literature (Table 2). All leachates had very high values of electrical conductivity, especially leachates B and C, which also exceeded the upper range value given in Table 2. The $\mathrm{pH}$ in the three leachates and the COD in leachates A and B belonged to the methanogenic waste decomposition phase (Kmet and McGinley, 1982; Stegman, 1982), which was consistent with the age of the sealed landfills.

The leachates had high concentrations of $\mathrm{Cl}^{-}, \mathrm{SO}_{4}^{-}$, $\mathrm{HCO}_{3}^{-}, \mathrm{Mg}$, and especially of $\mathrm{Na}$, but the $\mathrm{NO}_{3}^{-}, \mathrm{CO}_{3}^{-}$, $\mathrm{PO}_{4}^{=}$, and $\mathrm{F}^{-}$content was low. The $\mathrm{SO}_{4}^{=}, \mathrm{Ca}$, and $\mathrm{Mg}$ concentrations in leachate $\mathrm{B}$ were much higher than in the others. In addition, the $\mathrm{K}$ and $\mathrm{NH}_{4}^{+}$concentrations were very high in leachate $\mathrm{C}$.

With the basic $\mathrm{pH}$ values of around 8.0 and 9.1, the $\mathrm{HCO}_{3}^{-}$concentrations in the leachates are very much higher than the $\mathrm{CO}_{3}^{=}$content. The $\mathrm{NO}_{3}^{-}$concentrations are low in the leachates and the $\mathrm{NH}_{4}^{+}$is higher because of the anaerobic condition of the landfill leachates (Stegman, 1982). The $\mathrm{NH}_{4}^{+}$also exceeds the range assigned to leachates by Bramryd (1988) and Gordon et al. (1989), (i.e., $37-131 \mathrm{mg} / \mathrm{L}$ ). The $\mathrm{PO}_{4}^{=}$is also very low or non-existent in the leachates (Kmet and McGinley, 1982).

According to the range reported for trace elements (Table 2) in the literature, the most frequent and potential higher levels of trace elements in leachates from landfills are $\mathrm{Fe}, \mathrm{Mn}, \mathrm{Zn}$, and B. Husain et al. (1989) reported that with predominantly anaerobic conditions in landfills leachates contain high concentrations of chemically reduced inorganic substances, such as $\mathrm{NH}_{3}$, $\mathrm{Fe}, \mathrm{Mn}$, and $\mathrm{Zn}$. The values of these elements in the leachates were at the lower limit of their range (Table 2) compared with those found in the literature. The Mn concentration was higher in leachate $A$ than in the others, while the $\mathrm{Fe}, \mathrm{B}$, and $\mathrm{Zn}$ concentrations were the highest in leachate C. Leachate B had intermediate concentrations of all the trace elements analyzed compared with those of leachates $\mathrm{A}$ and $\mathrm{C}$, although $\mathrm{Zn}$ was very similar in all three. The low concentration of $\mathrm{Fe}, \mathrm{Mn}$, and $\mathrm{Zn}$ also corresponded to the methanogenic waste decomposition phase (Petruzzelli and Helfferich, 1989).

\section{The Trace Element Concentrations in Plants}

The results of the trace elements analysis of plants showed a differential accumulation of trace elements in the plant tissue of the four species (Table 3). The B concentration was higher in the clovers than in the grasses, while the concentrations of $\mathrm{Zn}$ and $\mathrm{Mn}$ were, in general, more similar in all four species. When the legume species were compared, the Fe concentration tended to be higher in T. glomeratum, while B tended to be higher in T. tomentosum. As regards the grass species, $H$. murinum accumulated more $\mathrm{Zn}$ than $B$. hordaceus, while the latter took up more $\mathrm{B}$ and $\mathrm{Fe}$. The legume species accumulate more $\mathrm{Fe}$ than grasses both in the deionized water and leachate treatments. Similar results were shown by Kabata-Pendias and Pendias (1984) and Pastor et al. (1995).

Watering with the three leachate treatments, generally increased the $\mathrm{Fe}$ and $\mathrm{Mn}$ concentrations in both clover plants compared with their control plants, while the $\mathrm{B}$ concentration decreased or remained quite similar. The $\mathrm{Zn}$ concentration also increased in $T$. glomeratum. On the other hand, $H$. murinum increased its Fe concentration under leachates A and B. However, the concentrations of all the trace elements analyzed remained similar with deionized water and leachates in B. hordaceus.

With all three leachate treatments, $T$. glomeratum was the species with the highest number of significant

Table 3. Chemical analysis and dry weight of the four plant species tested on soils treated with deionized water or leachates as well as results of the analysis of variance with one grouping factor (treatment) and with three leachates.

\begin{tabular}{|c|c|c|c|c|c|c|c|c|c|c|}
\hline \multirow[b]{2}{*}{ Species and treatments } & \multicolumn{2}{|l|}{$\mathbf{B}$} & \multicolumn{2}{|l|}{$\mathbf{Z n}$} & \multicolumn{2}{|l|}{$\mathbf{F e}$} & \multicolumn{2}{|l|}{ Mn } & \multicolumn{2}{|c|}{ Dry wt, g } \\
\hline & $\overline{\boldsymbol{x}} \pm \mathbf{S E}$ & $F$-value & $\bar{x} \pm \mathbf{S E}$ & $F$-value & $\bar{x} \pm \mathbf{S E}$ & $F$-value & $\overline{\boldsymbol{x}} \pm \mathbf{S E}$ & $F$-value & $\bar{x} \pm \mathbf{S E}$ & $F$-value \\
\hline Legume species & & & & & & & & & $-\mathbf{g}$ & \\
\hline $\begin{array}{l}\text { Trifolium glomeratum } \\
\text { Deionized water } \\
\text { Leachate A } \\
\text { Leachate B } \\
\text { Leachate C }\end{array}$ & $\begin{array}{l}41.67 \pm 0.33 \\
55.00 \pm 7.82 \\
34.67 \pm 0.88 \\
35.67 \pm 1.45\end{array}$ & $\begin{array}{c}-\overline{2.91} \\
55.13^{* *} \\
16.20^{*}\end{array}$ & $\begin{aligned} 61.00 & \pm 0.58 \\
100.22 & \pm 14.71 \\
80.33 & \pm 1.77 \\
66.00 & \pm 0.58\end{aligned}$ & $\begin{array}{c}-\overline{7.00} \\
108.52 * * * \\
37.50 * *\end{array}$ & $\begin{array}{l}175.00 \pm 2.89 \\
282.33 \pm \mathbf{3 2 . 9 8} \\
340.00 \pm \mathbf{2 3 . 1 2} \\
136.67 \pm \mathbf{8 . 8 3}\end{array}$ & $\begin{array}{l}-\overline{-} \\
10.54 * \\
50.26 * * \\
17.06 *\end{array}$ & $\begin{array}{l}\mathbf{2 8 . 6 7} \pm \mathbf{5 . 7 9} \\
\mathbf{9 3 . 0 0} \pm \mathbf{1 9 . 4 2} \\
\mathbf{3 0 . 0 0} \pm \mathbf{5 . 7 8} \\
\mathbf{3 7 . 0 0} \pm \mathbf{3 . 5 2}\end{array}$ & $\begin{array}{c}-\overline{10} \\
0.03 \\
1.52\end{array}$ & $\begin{array}{l}0.206 \pm 0.072 \\
0.216 \pm 0.081 \\
0.300 \pm 0.121 \\
0.165 \pm 0.049\end{array}$ & $\begin{array}{r}0 . \overline{2} \\
1.34 \\
0.66\end{array}$ \\
\hline $\begin{array}{l}\text { Trifolium tomentosum } \\
\text { Deionized water } \\
\text { Leachate A } \\
\text { Leachate B } \\
\text { Leachate C }\end{array}$ & $\begin{array}{l}64.00 \pm 1.73 \\
64.67 \pm 1.20 \\
69.00 \pm 2.00 \\
68.00 \pm 1.16\end{array}$ & $\begin{array}{l}-\overline{10} \\
3.57 \\
3.69\end{array}$ & $\begin{array}{l}74.00 \pm 0.58 \\
67.00 \pm \mathbf{5 . 0 1} \\
\mathbf{8 3 . 0 0} \pm \mathbf{2 . 6 5} \\
\mathbf{7 3 . 3 3} \pm \mathbf{2 . 3 4}\end{array}$ & $\begin{array}{c}\overline{-} \\
1.93 \\
11.05 * \\
1.92\end{array}$ & $\begin{array}{l}156.67 \pm 21.88 \\
170.00 \pm 15.29 \\
256.67 \pm 63.67 \\
163.00 \pm 6.51\end{array}$ & $\begin{array}{l}-\overline{0.25} \\
2.21 \\
0.08\end{array}$ & $\begin{array}{l}\mathbf{4 6 . 6 7} \pm \mathbf{3 . 3 4} \\
\mathbf{5 3 . 3 3} \pm \mathbf{8 . 8 3} \\
\mathbf{5 0 . 0 0} \pm \mathbf{1 0 . 0 1} \\
\mathbf{6 0 . 0 0} \pm \mathbf{5 . 7 8}\end{array}$ & $\begin{array}{l}-\overline{0.50} \\
0.10 \\
4.00\end{array}$ & $\begin{array}{l}0.496 \pm 0.119 \\
0.531 \pm 0.266 \\
0.367 \pm 0.099 \\
0.149 \pm 0.072\end{array}$ & $\begin{array}{c}0 . \overline{0} \\
2.05 \\
18.63^{* * *}\end{array}$ \\
\hline $\begin{array}{l}\text { Grass species } \\
\text { Hordeum murinum } \\
\text { Deionized water } \\
\text { Leachate A } \\
\text { Leachate B } \\
\text { Leachate C }\end{array}$ & $\begin{array}{l}19.00 \pm 0.58 \\
18.33 \pm 2.41 \\
22.67 \pm 3.29 \\
19.00 \pm 2.00\end{array}$ & $\begin{array}{l}- \\
0.07 \\
1.21 \\
0.00\end{array}$ & $\begin{aligned} 93.67 & \pm 17.66 \\
100.33 & \pm 17.38 \\
105.33 & \pm 8.42 \\
92.67 & \pm 7.76\end{aligned}$ & $\begin{array}{l}- \\
0.07 \\
0.36 \\
0.00\end{array}$ & $\begin{array}{l}133.33 \pm 3.34 \\
153.33 \pm 23.36 \\
166.67 \pm \mathbf{8 . 8 3} \\
143.33 \pm 6.67\end{array}$ & $\begin{array}{c}- \\
0.72 \\
12.50^{*} \\
1.80\end{array}$ & $\begin{array}{l}50.00 \pm \mathbf{5 . 7 8} \\
\mathbf{6 3 . 3 3} \pm \mathbf{1 3 . 3 5} \\
\mathbf{7 0 . 0 0} \pm \mathbf{1 1 . 5 6} \\
\mathbf{5 0 . 0 0} \pm \mathbf{0 . 0 0}\end{array}$ & $\begin{array}{l}-\overline{84} \\
2.40 \\
0.00\end{array}$ & $\begin{array}{l}\mathbf{0 . 6 3 5} \pm 0.261 \\
0.936 \pm 0.179 \\
0.985 \pm 0.230 \\
0.358 \pm 0.045\end{array}$ & $\begin{array}{l}3 . \overline{33} \\
3.68 \\
4.74^{*}\end{array}$ \\
\hline $\begin{array}{l}\text { Bromus hordaceus } \\
\text { Deionized water } \\
\text { Leachate A } \\
\text { Leachate B } \\
\text { Leachate C } \\
\end{array}$ & $\begin{array}{l}35.00 \pm 5.04 \\
34.33 \pm 0.02 \\
\mathbf{4 2 . 0 0} \pm \mathbf{2 . 0 8} \\
\mathbf{3 4 . 3 3} \pm \mathbf{2 . 9 1}\end{array}$ & $\begin{array}{l}- \\
0.02 \\
1.65 \\
0.01\end{array}$ & $\begin{array}{l}87.33 \pm 9.34 \\
80.67 \pm 3.18 \\
79.00 \pm 2.52 \\
85.67 \pm 5.49\end{array}$ & $\begin{array}{l}- \\
0.46 \\
0.74 \\
0.02\end{array}$ & $\begin{array}{l}190.00 \pm 30.59 \\
200.00 \pm 10.01 \\
170.00 \pm 15.29 \\
210.00 \pm 2312 \\
\end{array}$ & $\begin{array}{l}- \\
0.10 \\
0.34 \\
0.27\end{array}$ & $\begin{array}{l}47.33 \pm 7.34 \\
46.67 \pm \mathbf{3 . 3 4} \\
\mathbf{5 3 . 3 3} \pm \mathbf{3 . 3 4} \\
\mathbf{4 8 . 3 3} \pm \mathbf{4 . 4 1} \\
\end{array}$ & $\begin{array}{l}-\overline{0.01} \\
0.55 \\
0.01\end{array}$ & $\begin{array}{l}0.663 \pm 0.036 \\
0.558 \pm 0.099 \\
0.689 \pm 0.112 \\
0.184 \pm 0.079 \\
\end{array}$ & $\begin{array}{c}2.97 \\
0.15 \\
92.15^{* * *} \\
\end{array}$ \\
\hline
\end{tabular}

$*, * *, * * * P<0.05,0.01$, and 0.001 , respectively. 
alterations of the trace element concentrations compared with the control plants. In this species, the least contaminated leachate (leachate A) only had a significant effect on the $\mathrm{Fe}$ and $\mathrm{Mn}$ concentrations (Table 3). There was a trend to increase the $\mathrm{Zn}$ concentration $(P=$ 0.0574). In $T$. glomeratum, watering with leachate B, increased significantly the $\mathrm{Zn}(P<0.001)$ and $\mathrm{Fe}$ $(P<0.01)$ concentrations. However, the B concentration decreased in these species $(P<0.05)$. The $\mathrm{Zn}$ concentration also increased significantly $(P<0.05)$ in $T$. glomeratum with the leachate B treatment, while $\mathrm{Fe}$ increased $(P<0.05)$ in $H$. murinum with the same leachate treatment. Again, the leachate $\mathrm{C}$ treatment only had a significant effect on $T$. glomeratum, in which $\mathrm{Zn}$ increased $(P<0.01)$ and the Fe and $\mathrm{B}$ decreased $(P<0.05)$.

The legume species were more affected by the leachate treatment than the grasses, especially $T$. glomeratum, which had a higher number of significant changes in trace element concentrations than the others in the three leachate treatments. The nutritional behavior of T. glomeratum was affected most, which is consistent with the fact that this species (of all four) is the most representative in natural nonpolluted pastures. Trifolium tomentosum, however, is the species most representative of pastures subjected to anthropogenic action the same as $B$. hordaceus with a broad ecological spectrum, but rather ruderal, while $H$. murinum is clearly ruderal. In addition, the results show that the higher increase of the trace element concentrations in the plants were not in accordance with higher trace element concentrations in leachates. Thus, the $\mathrm{B}, \mathrm{Zn}$, and $\mathrm{Fe}$ increase in the plant tissues was not the highest with leachate $\mathrm{C}$ (containing higher $\mathrm{B}, \mathrm{Zn}$, and $\mathrm{Fe}$ concentrations than the leachates $A$ and $B$, Table 2). On the contrary, Fe and B decreased significantly (e.g., in T. glomeratum) with the leachate C treatment. Only Mn experienced the greatest increase in $T$. glomeratum with the leachate $\mathrm{C}$ treatment (containing a higher $\mathrm{Mn}$ concentration than the others, Table 2).

Interactions between the micronutrients and other divalent cations in plant absorption may partly explain these results. Similarly, Kabata-Pendias and Pendias (1984), Graham et al. (1987), Marschner (1993), and Loneragan and Webb (1993) reported antagonistic interactions of $\mathrm{Fe}-\mathrm{B}, \mathrm{Zn}-\mathrm{B}$, and $\mathrm{Fe}-\mathrm{Zn}$ in the absorption of these elements by the plant. Thus, the significant decrease of $\mathrm{B}$ and a significant $\mathrm{Zn}$ and $\mathrm{Fe}$ increase in T. glomeratum with the leachate B treatment (Table 3 ) may be explained by these nutrient interactions. The same interactions may explain the significant decrease of $\mathrm{B}$ and $\mathrm{Fe}$ as well as the significant increase of $\mathrm{Zn}$ when the clover receives the leachate $\mathrm{C}$ treatment (Table 3 ).

On the other hand, the assessment of trace element toxicity is difficult because sufficient and excessive concentrations are often reported as ranges and are not easily associated with specific soil-plant systems. Nevertheless, general sufficiency ranges taken from the literature were compared with the observed concentrations in the plant tissue (Table 4). This table summarizes the average range of $\mathrm{B}, \mathrm{Zn}, \mathrm{Fe}$, and $\mathrm{Mn}$ in forage plants
Table 4. Average range of $\mathrm{B}, \mathrm{Zn}, \mathrm{Fe}$, and $\mathrm{Mn}$ concentrations from literature and clover and grasses watered with deionized water and leachates.

\begin{tabular}{|c|c|c|c|c|}
\hline & \multirow{2}{*}{$\frac{\text { B }}{\text { Avg. }}$} & \multirow{2}{*}{$\begin{array}{c}\text { Zn } \\
\text { Avg. } \\
\text { range }\end{array}$} & \multirow{2}{*}{$\begin{array}{c}\text { Fe } \\
\text { Avg. } \\
\text { range }\end{array}$} & \multirow{2}{*}{$\begin{array}{l}\text { Mn } \\
\text { Avg. } \\
\text { range }\end{array}$} \\
\hline & & & & \\
\hline & & $-\mathbf{m g}$ & -1 & \\
\hline $\begin{array}{l}\text { Critical deficiency levels } \\
\text { Sufficient or normal levels } \\
\text { Excessive or toxic levels }\end{array}$ & $\begin{array}{c}5-30 \\
- \\
80-330\end{array}$ & $\begin{array}{c}10-20 \\
27-150 \\
100-400\end{array}$ & $\begin{array}{c}-\overline{10-300} \\
1000\end{array}$ & $\begin{array}{r}15-25 \\
20-300 \\
300-500\end{array}$ \\
\hline $\begin{array}{l}\text { Concentrations in clovers A } \dagger \\
\text { Concentrations in clovers B } \\
\text { Concentrations in clovers C } \\
\text { Concentrations in clovers D }\end{array}$ & $\begin{array}{c}37 \\
- \\
42-64 \\
39-69\end{array}$ & $\begin{array}{l}24-45 \\
7-15 \\
61-74 \\
66-100\end{array}$ & $\begin{array}{c}74-400 \\
23-56 \\
157-175 \\
137-340\end{array}$ & $\begin{array}{l}- \\
19-25 \\
29-47 \\
30-60\end{array}$ \\
\hline $\begin{array}{l}\text { Concentrations in grasses A } \\
\text { Concentrations in grasses B } \\
\text { Concentrations in grasses C } \\
\text { Concentrations in grasses D }\end{array}$ & $\begin{array}{c}5.7 \\
- \\
19-35 \\
18-42\end{array}$ & $\begin{array}{c}12-47 \\
5-39 \\
87-94 \\
79-105\end{array}$ & $\begin{array}{r}43-376 \\
12-476 \\
133-190 \\
143-200\end{array}$ & $\begin{array}{l}- \\
17-46 \\
47-50 \\
47-70\end{array}$ \\
\hline
\end{tabular}

$\dagger$ Concentrations A: content of forage plants from various countries (Kabata-Pendias and Pendias, 1984; Cureton et al., 1991; Marschner, 1993). Concentrations $B$ : content in the legume and grass species from natural grassland of a semiarid environments (Garcia et al., 1982; Ortega and Garcia, 1987; Pastor et al., 1992, 1995). Concentrations C: data from clover and grass species, receiving the deionized water treatment in this study. Concentrations D: data from clover and grass species, receiving leachate treatments in this study.

from various countries (Kabata-Pendias and Pendias, 1984; Cureton et al., 1991; Marschner, 1993), the concentrations in legume and grass species from natural grassland of semiarid environments in central Spain (García et al., 1982; Ortega and García, 1987; Pastor et al., 1992, 1995) and the respective data for the clover and grass species watered with deionized water and leachates in this study.

Although the data in Table 4 suggest that, in general, the concentrations of the analyzed elements in clover and grasses watered with leachates are in the range of normal values in the literature, they generally did not reach values considered toxic or deficient. With a more detailed picture of these data, the average range of $\mathrm{Zn}$ in the clover and grasses tested and the average range of $\mathrm{Fe}$ in the clover were higher than the respective concentrations in legumes and grasses from a natural grassland in a semiarid environment of central Spain, while the average ranges of $\mathrm{Mn}$ and $\mathrm{Fe}$ in the grasses were similar to the former. In some cases, the average range of $\mathrm{Zn}$ in the clover and grasses watered with landfill leachates reached the excessive or toxic levels reported in literature $\left(100-400 \mathrm{mg} \mathrm{L}^{-1}\right)$. The average range of $\mathrm{Zn}$ in the legumes with leachates was 62 to 125 $\mathrm{mg} \mathrm{L}^{-1}$ and in the grasses it was 66 to $122 \mathrm{mg} \mathrm{L}^{-1}$. Trifolium glomeratum and $H$. murinum were the plant species with the highest $\mathrm{Zn}$, but no visual Zn-phytotoxicity symptoms were observed at harvest (Table 3 ). The results show that $\mathrm{Zn}$ is the greatest threat among the trace elements studied, while the levels of $\mathrm{Mn}$ and B increased relatively little compared with the corresponding control plants. The $\mathrm{Mn}, \mathrm{Fe}$, and B concentration ranges were very far from their excessive or toxic levels.

In summary, the results showed that the $\mathrm{B}, \mathrm{Fe}$, and $\mathrm{Mn}$ accumulated in the plant tissue with leachate treatment were in the range of values reported as normal. In some cases, $\mathrm{Zn}$ in $T$. glomeratum and $H$. murinum exposed 
Table 5. $F$ values from analysis of variance of the plant trace element concentrations and dry weight with two grouping factors (species and treatment) and three leachates.

\begin{tabular}{|c|c|c|c|c|c|}
\hline Source of variation & B & $\mathbf{Z n}$ & $\mathbf{F e}$ & Mn & Dry wt. \\
\hline & & & $F$-values & & \\
\hline $\begin{array}{l}\text { Deionized water and } \\
\text { leachate A treatment } \\
\mathbf{S}=\text { Species } \\
\mathbf{T}=\text { Treatment } \\
\mathbf{S}-\mathbf{T}\end{array}$ & $\begin{array}{l}60.32 * * * \\
1.60 \\
1.85\end{array}$ & $\begin{array}{l}2.01 \\
1.08 \\
1.96\end{array}$ & $\begin{array}{l}6.58 * * \\
6.69 * \\
2.56\end{array}$ & $\begin{array}{l}0.81 \\
9.04 * * \\
4.49 *\end{array}$ & $\begin{array}{l}14.93 * * * \\
0.93 \\
1.89\end{array}$ \\
\hline $\begin{array}{l}\text { Deionized water and } \\
\text { leachate B treatment } \\
\mathbf{S}=\text { Species } \\
\mathbf{T}=\text { Treatment } \\
\mathbf{S}-\mathbf{T}\end{array}$ & $\begin{array}{c}117.39 * * * \\
1.54 \\
3.22\end{array}$ & $\begin{array}{l}4.88 * * \\
2.06 \\
1.12\end{array}$ & $\begin{array}{c}5.27 * \\
12.26 * * \\
4.09 *\end{array}$ & $\begin{array}{l}6.43 * * \\
2.30 \\
0.70\end{array}$ & $\begin{array}{l}18.89 * * * \\
2.23 \\
\mathbf{3 . 0 3}^{*}\end{array}$ \\
\hline $\begin{array}{l}\text { Deionized water and } \\
\text { leachate C treatment } \\
\mathbf{S}=\text { Species } \\
\mathbf{T}=\text { Treatment } \\
\mathbf{S}-\mathbf{T}\end{array}$ & $\begin{array}{c}136.90^{* * *} \\
0.16 \\
1.51\end{array}$ & $\begin{array}{l}5.46 * * \\
0.06 \\
0.09\end{array}$ & $\begin{array}{l}5.11 * \\
0.00 \\
1.26\end{array}$ & $\begin{array}{l}6.68^{* *} \\
2.61 \\
0.81\end{array}$ & $\begin{array}{c}10.51^{* * *} \\
47.22^{* * *} \\
4.86^{* *}\end{array}$ \\
\hline
\end{tabular}

$*, * *, * * * P<0.05,0.01,0.001$, respectively.

to leachates had reached a toxic level, but no visual symptoms of $\mathrm{Zn}$ phytotoxicity were obseved. Thus, special attention to the $\mathrm{Zn}$ should be paid to basic soil environments affected by landfills leachates.

\section{Dry Weight of the Plants}

The weights of the four plant species were significantly less after the leachate $\mathrm{C}$ treatment than that of the controls (Table 3). The weight decreases in the plants were very highly significant $(P<0.001)$ in $T$. tomentosum and $B$. hordaceus and significant $(P<0.05)$ in $H$. murinum. The reductions in dry weight were about 20, 70, 44, and 72\%, respectively, in $T$. glomeratum, $T$. tomentosum, $H$. murinum, and B. hordaceus after the leachate $\mathrm{C}$ treatment. With leachates $\mathrm{A}$ and $\mathrm{B}$, however, $H$. murinum and $T$. glomeratum increased their weight with leachate B addition, though not significantly.

The weight reduction in the plants is attributed to the very high conductivity values in soil solution from the leachate $B$ and $C$ treatments (which were $12.5 \mathrm{mS} \mathrm{cm}^{-1}$ and $25.125 \mathrm{mS} \mathrm{cm}^{-1}$, respectively) and not to potential $\mathrm{Zn}$ phytotoxicity. The $\mathrm{Zn}$ in the plants with leachate $\mathrm{C}$ (when plants had the highest weight reduction) were very similar in all the plant species compared with that of the control plants, while the plants did not have less dry weight (Table 3) with a higher $\mathrm{Zn}$ content (e.g., in $T$. glomeratum and $H$. murinum with leachates $A$ and B). The symptoms observed in the species with leachate $\mathrm{C}$ were quite similar to those observed under severe salinity stress. In addition, electric conductivity (EC) in the soils watered with leachates $\mathrm{B}$ and $\mathrm{C}$ exceeds the threshold levels established by plant ecologists $(7 \mathrm{mS}$ $\mathrm{cm}^{-1}$ ) and plant physiologists (11 $\mathrm{mS} \mathrm{cm}^{-1}$ ) (Le Houérou, 1993). Electrical conductivity in soils receiving the leachate A treatment exceeds the threshold level commonly established by soil scientists for a soil considered saline ( $4 \mathrm{mS} \mathrm{cm}^{-1} \mathrm{EC}$ ) (Le Houérou, 1993).

As with the trace elements concentrations in the plants, the dry weight response and the signs of vitality to leachate exposure differed among the four species. According to Fletcher et al. (1990), the taxonomic differences between plants is a very important factor in plant response to chemical toxicity. The ANOVA using the trace element content and dry weight of all the plants with two grouping factors (species and treatment) reflected the great influence of the species factor in the response of plants to leachate, but the treatment factor also was significant in some cases (Table 5). Thus, the species factor, in general, had the highest $F$-values for $\mathrm{B}, \mathrm{Zn}, \mathrm{Fe}, \mathrm{Mn}$, and dry weight with all three leachate treatments. The species factor had highly significant $F$-values $(P<0.001)$ for $\mathrm{B}$ and dry weight with the three leachate treatments. For $\mathrm{Zn}$, the species factor was significant $(P<0.05)$ with leachate $\mathrm{B}$ and highly significant $(P<0.01)$ with leachate $\mathrm{C}$. The same factor was also highly significant $(P<0.01)$ for Fe with leachate $\mathrm{A}$ and significant $(P<0.05)$ with leachates $\mathrm{B}$ and $\mathrm{C}$, and highly significant $(P<0.01)$ for $\mathrm{Mn}$ under leachates B and C. But the treatment and the speciestreatment interaction factors also had an important influence on the plant response to the leachate supply.

In short, the results confirm how much the varying response of the species reacts to the leachate supply species had the highest degree of statistical significance for most of the parameters analyzed. The treatment and species-treatment interations had very significant $F$ - values.

\section{Chemical Soil Properties after Harvest}

Some of the properties of the soil used in the experiment may help in reducing an excessive accumulation of trace elements in the plant. Watering with the three leachates significantly decreased the soil $\mathrm{pH}(P<0.001)$ for all three leachates (Table 6). Soil $\mathrm{pH}$ has been identified as the most decisive factor in the regulation of micronutrient availability as it influences the distribution of the micronutrients in the soil (Shuman, 1986; Marschner, 1993; Tack et al., 1996). In general, most trace elements (including $\mathrm{B}, \mathrm{Zn}, \mathrm{Fe}$, and $\mathrm{Mn}$ ) increase their availability in acid soil (Iyengar et al., 1981; Kabata-Pendias and Pendias, 1984; Brieger et al., 1992;

Table 6. Chemical analysis of the soils under deionized water or under leachates $A, B$, and $C$ and analysis of variance for the soil concentrations with one grouping factor (treatment) and the three leachates.

\begin{tabular}{|c|c|c|c|c|c|c|c|}
\hline \multirow[b]{2}{*}{ Soil parameters } & \multirow{2}{*}{$\frac{\begin{array}{c}\text { Soils with } \\
\text { deionized water }\end{array}}{\overline{\boldsymbol{x}} \pm \mathrm{SE}}$} & \multicolumn{2}{|c|}{$\begin{array}{r}\text { Soils with } \\
\text { leachate A }\end{array}$} & \multicolumn{2}{|c|}{$\begin{array}{l}\text { Soils with } \\
\text { leachate B }\end{array}$} & \multicolumn{2}{|c|}{$\begin{array}{l}\text { Soils with } \\
\text { leachate C }\end{array}$} \\
\hline & & $\bar{x} \pm \mathbf{S E}$ & $F$-value & $\bar{x} \pm \mathbf{S E}$ & $F$-value & $\overline{\boldsymbol{x}} \pm \mathbf{S E}$ & $F$-value \\
\hline $\begin{array}{l}\text { pH } \\
\text { Conductivity, } \mu \mathrm{S} \mathrm{cm}^{-1} \\
\text { Organic matter, \% } \\
\text { CEC, meq/100 } \mathrm{g}\end{array}$ & $\begin{aligned} 7.7 & \pm 0.1 \\
1882.5 & \pm 151.6 \\
5.1 & \pm 0.2 \\
36.84 & \pm 0.59\end{aligned}$ & $\begin{aligned} 7.4 & \pm 0.1 \\
6225.0 & \pm 311.9 \\
4.9 & \pm 0.1 \\
39.05 & \pm 0.58\end{aligned}$ & $\begin{array}{c}50.00^{* * *} \\
156.80^{* * *} \\
0.60 \\
28.49 * *\end{array}$ & $\begin{aligned} 7.5 & \pm 0.1 \\
12500.0 & \pm 294.4 \\
4.6 & \pm 0.1 \\
.56 .20 & \pm 0.92\end{aligned}$ & $\begin{array}{c}18.00^{* *} \\
1028.20 * * * \\
3.75 \\
1259.99 * * *\end{array}$ & $\begin{aligned} 7.3 & \pm 0.1 \\
25125.0 & \pm 1476.7 \\
4.7 & \pm 0.1 \\
57.38 & \pm 2.74\end{aligned}$ & $\begin{array}{c}123.86 * * * \\
245.15^{* * *} \\
3.31 \\
214.44^{* * *}\end{array}$ \\
\hline
\end{tabular}

$*, * *, * * * P<0.05,0.01,0.001$, respectively. 
Chaney, 1993). The $\mathrm{pH}$ values (between 7.3-7.5) found in the soils treated with leachates may increase the insolubility of high quantities of trace elements, thus reducing their bioavailability and excessive accumulation in the species tested.

On the other hand, soil salinity and CEC increased with leachate watering compared with control soils. These increases were progressively higher as EC increased in leachates $\mathrm{A}, \mathrm{B}$, and $\mathrm{C}$, respectively, and were significant $(P<0.001)$. The increase in soil conductivity may also diminish the availability of trace elements to plants (Otte et al., 1993). The CEC significantly increased in the soils for leachate $\mathrm{A}(P<0.01)$ and for leachates $\mathrm{B}$ and $\mathrm{C}(P<0.001)$. The highest CEC increase found in the soils with leachates $B$ and $C$ was in accordance with the highest cation concentrations in these leachates compared with leachate A.

A significant increase in soil salinity was reported in the surface soil samples from the areas affected by landfill leachates in central Spain and a climate with semiarid characteristics (400-600 mm annual rainfall) (Pastor et al., 1993a; Pastor et al., 1993b; Hernández et al., 1998). The salinity of the soils contaminated by landfill leachates may have a negative effect in semiarid areas where salinity problems are not uncommon. In such areas with little rain and high evaporation, the excessive salt content of the soil is not easily leached (Ortiz, 1990).

\section{CONCLUSIONS}

According to Alvarado et al. (1995), the research of wild plant nutrition is of interest to improve the management of ecosystems that depend on the knowledge of ecological and nutritional characteristics of the species to be managed. In this way, the results from the present bioassays may help to improve the guidelines for investigating the potential effects of landfill leachates on the trace element concentrations in wild plants, their tolerance, or sensitivity to leachate exposure and their potential value for the revegetation of areas degraded by landfill leachates. Plant toxicity testing is particularly valuable when complex mixtures or complex effluents are evaluated and the U.S. Environmental Protection Agency is currently developing a biomonitoring strategy in which phytotoxicity tests are recommended as essential (Wang, 1992). The results of the ecotoxicological experiment for ecologically relevant organisms have proved to be extremely useful for assessing new chemicals and establishing criteria for the highest acceptable concentrations in the environment (Wang, 1992).

The legumes and grasses may have a potential value for the revegetation of degraded areas affected by landfill leachates with low trace element concentrations in semiarid regions and similar soil properties to those used in this study, but with a salinity level below $6 \mathrm{mS}$ $\mathrm{cm}^{-1}$, which were tolerated by the four species tested.

\section{ACKNOWLEDGMENTS}

The authors gratefully acknowledge the financial support provided by the CICYT, project AMB95-0108.

\section{REFERENCES}

Adarve, M.J., A.J. Hernández, and J. Pastor. 1995. Degradación química de suelos de la Comunidad de Madrid por la incidencia de dos vertederos de residuos sólidos urbanos. p. 13-21. In Dep. de Edafología (ed.) Degradación y conservación de suelos. Facultad de Farmacia, Univ. Complutense de Madrid, Madrid, Spain.

Adarve, M.J., A.J. Hernández, J. Pastor, and S. Oliver. 1994. Contribución de los vertederos de residuos sólidos urbanos a la salinización y nitrificación del suelo sobre sustratos básicos. p. 21-24. In Proc. of II Int. Congress of Contaminated Soils, Vitoria-Gasteiz, Spain. 21-22 Sept. 1994. IHOBE (Sociedad Publica Gestion Ambiental) and Dep. de Urbanismo, Vivienda y Medio Ambiente del Gobierno Vasco, Vitoria-Gasteiz, Spain.

Adarve, M.J., and L.F. Rebollo. 1993. Incidencia ambiental de un vertedero sellado de residuos sólidos localizado en Móstoles (Madrid) sobre la composición de las aguas subterráneas. Geogaceta $13: 3-6$.

Alvarado, J.J., J.L. Valenzuela, A. Sánchez, and L. Romero. 1995. Iron nutrition in wild plants growing in two different soils. p. 141-145. In J. Abadia (ed.) Iron nutrition in soils and plants. Kluwer Academic Publ., the Netherlands.

BMDP Statistical Software package. 1993. University of California Press, Berkeley-Los Angeles-Oxford.

Bramryd, T. 1988. Leachate from landfills-A valuable fertilizer for revegetation of landfills with grass or energy forest. ISWA Proc. 2:61-68.

Brieger, G., J.R. Wells, and R.D. Hunter, 1992. Plant and animal species composition and heavy metal content in fly ash ecosystems. Water Air Soil Pollut. 63:87-103.

Chaney, R.L. 1993. Zinc phytotoxicity. p. 135-150. In A.D. Robson (ed.) Zinc in soils and plants. Kluwer Academic Publ., the Netherlands.

Christensen, T.H., J. Lyngkilde, and P. Kjeldsen. 1992. Fate of landfill leachate pollutants in groundwater. A field study at the old Vejen landfill (Denmark). p. 1-12. In ATEGRUS (ed.) ISWA Proc. 6th Int. Solid Wastes Congress. 14-19 June 1992. Asociación Técnica para la Gestión de Residuos y Medio Ambiente, Madrid.

Clark, T.P., and R. Piskin. 1977. Chemical quality and indicator parameter for monitoring landfill leachate in Illinois. Environ. Geol. 1:329-339.

Cureton, P.M., P.H. Groenevelt, and R.A. McBride. 1991. Landfill leachate recirculation: Effects on vegetation vigor and clay surface cover infiltration. J. Environ. Qual. 20:17-24.

Cyr, F., M.C. Mehra, and V.N. Mallet. 1987. Leaching of chemical contaminants from municipal landfill sites. Bull. Environ. Contam. Toxicol. 38:775-782.

Fletcher, J.S., F.L. Johnson, and S.C. Mc Farlane. 1990. Influence of greenhouse versus field testing and taxonomic differences on plant sensitivity to chemical treatment. Environ. Toxicol. Chem. 9: 769-777.

García, B., A. García, M.I. Montalvo, and L. García. 1982. Producción y extracción de bioelementos en pastizales naturales y especies pratenses cultivadas. An. Edafol. 7-8:1415-1437.

Gordon, A.M., R.A. McBride, A.J. Fisken, and T.E. Bates. 1989. Effect of landfill leachate irrigation on red maple (Acer rubrum L.) and sugar maple (Acer saccharum Marsh) seeding growth and on foliar nutrient concentrations. Environ. Pollut 56:327-336.

Graham, R.D., R.M. Welch, D.L. Grunes, E.E. Cary, and W.A. Norwell. 1987. Effect of zinc deficiency on the accumulation of boron and other mineral nutrients in barley. Soil Sci. Soc. Am. J. 51: $652-657$.

Hernández, A.J., M.J. Adarve, and J. Pastor. 1998. Some impacts of urban waste landfills on Mediterranean soils. Land Degradation Develop. 9:21-33.

Hernández, A.J., and J. Pastor. 1989. Técnicas analíticas para el estudio de las interacciones suelo-planta. Henares, Rev. Geol. 3:67-102.

Husain T., A. Hoda, and R. Khan. 1989. Impact of sanitary landfill on groundwater quality. Water Air Soil Pollut. 45:191-206.

Issac, R.A., and J.D. Kerber, 1971. Atomic absorption and flame photometry: Techniques and uses in soil, plant and water analysis. p. 17-37. In L.M. Walsh (ed.) Instrumental methods for analysis of soils and plant tissue. SSSA, Madison, WI.

Iyengar, S.S., D.C. Martens, and W.P. Miller. 1981. Distribution and 
plant availability of soil zinc fractions. Soil Sci. Soc. Am. J. 42: 735-739.

Kabata-Pendias, A., and H. Pendias. 1984. Trace elements in soils and plants. CRC Press, Boca Raton, FL.

Kilmer, V.J., and L.T. Alexander. 1949. Methods of making mechanical analyses of soil. Soil Sci. 68:15-24.

Kmet, P., and P.M. McGinley. 1982. Chemical characteristics of leachate from municipal solid waste landfills in Wisconsin. p. 225-254. In V Annual Madison Conference on Applied Research and Practice on Municipal and Industrial Waste. Wisconsin. Dep. of Engineering and Applied Sciences, Univ. of Wisconsin, Madison.

Le Houérou, H.N. 1993. Salt-tolerant plants for the arid regions of the Mediterranean isoclimatic zone. p. 403-422. In $\mathrm{H}$. Lieth and A. Al Masoom (ed.) Towards the rational use of high salinity tolerant plants Vol.1. Kluwer Academic Publ., the Netherlands.

Loizidou, M., and E.G. Kapetanios. 1991. Effect of leachate from landfills on underground water quality. Sci. Total Environ. 128: 69-81.

Loneragan, J.F., and M.J. Webb. 1993. Interactions between zinc and other nutrients affecting the growth of plants. p. 119-134. In A.D. Robson (ed.) Zinc in soils and plants. Kluwer Academic Publ., the Netherlands.

Lorenz, S.E., R.E. Hamon, S.P. McGrath, P.E. Holm, and T.H. Christensen. 1994. Applications of fertilizer cations affect cadmium and zinc concentrations in soil solutions and uptake by plants. Eur. J. Soil Sci. 45:159-165.

Marschner, H. 1993. Zinc uptake from soils. p. 59-77. In A.D. Robson (ed.) Zinc in soils and plants. Kluwer Academic Publ., the Netherlands.

Ministerio de Agricultura, Pesca y Alimentación. 1982. Métodos oficiales de análisis de suelos y aguas. Servicio de Publicaciones del Ministerio de Agricultura, Pesca y Alimentación, Madrid, Spain.

Moreno, J.L., C. García, T. Hernández, and J.A. Pascual. 1996. Transference of heavy metals from a calcareous soil amended with sewage-sludge compost to barley plants. Bioresour. Technol. 55:251258.

Ortega Sánchez, C., and M.E. García López. 1987. Correlaciones entre los contenidos de $\mathrm{Fe}, \mathrm{Mn}$ y $\mathrm{Zn}$ en suelos y plantas de trigo. p. 141-148. In ANQUE (ed.) VII Congreso Nacional de Química Agrícola y Alimentaria, Sevilla, Spain. 12-17 Oct. 1987. Asociación Nacional de Químicos de España, Madrid.

Ortiz, R. 1990. Mecanismos y procesos de degradación del suelo con especial referencia a las condiciones ambientales mediterráneas. p. 47-68. In J. Albaladejo et al. (ed.) Soil degradation and rehabilitation in Mediterranean environmental conditions. Centro de Edafología y Biología Aplicada del Segura-Consejo Superior de Investigaciones Cientificas (CEBAS-CSICS), Madrid.
Otte, M.L., M.S. Haarsma, R.A. Broekman, and J. Rozema. 1993. Relation between heavy metal concentrations in salt marsh plants and soil. Environ. Pollut. 82:13-22.

Pastor, J., M. Alía, A.J. Hernández, M.J. Adarve, A. Urcelay, and F.A. Antón. 1993a. Ecotoxicological studies on effects of landfill leachates on plants and animals in Central Spain. Sci. Total Environ. Suppl. 1993:127-134.

Pastor, J., A.J. Hernández, M.J. Adarve, and A. Urcelay. 1993b. Chemical characteristics of sedimentary soils in the Mediterranean environment: A comparison of undisturbed and disturbed soils. Appl. Geochem. Suppl. Issue 2:195-198.

Pastor, J., A.J. Hernández, E. Estalrich, and S. Oliver. 1995. Soil factors and $\mathrm{Fe}$ content in wild herbaceous plants. p. 159-166. In J. Abadia (ed.) Iron nutrition in soils and plants. Kluwer Academic Publ., the Netherlands.

Pastor, J., S. Oliver, and A. Martín. 1992. Incidencia de las proximidades de las rutas de transporte de minerales sobre los micronutrientes de poblaciones herbaceas. Simposio Nacional sobre Nutrición Mineral de las Plantas:129-133. Alicante.

Pastor, J., A. Urcelay, A.J. Hernández, and A. García. 1993c. Investigations on the revegetation problems of landfill soils in a semiarid environment. p. 323-326. In H.J.P. Eijsackers and T. Hamers (ed.) Integrated soil and sediment research: A basis for proper protection. Kluwer Academic Publ., Dordrecht, the Netherlands.

Pastor, J., A. Urcelay A, S. Oliver, and A.J. Hernández. 1993d. Impact of municipal waste on Mediterranean dry environments. Geomicrobiol. J. 11:247-260.

Petruzzelli, D., and F.G. Helfferich. 1989. Migration and fate of pollutants in soils and subsoils. NATO ASI Ser. Ecol. Sci. 32:45-54.

Shuman, L.M. 1986. Effect of liming on the distribution of manganese, copper, iron, and zinc among soil fractions. Soil Sci. Soc. Am. J. 50:1236-1240.

Sridharan, L., and P. Didier. 1988. Leachate quality from containment landfills in Wisconsin. ISWA Proc. 2:133-138.

Stegman, R. 1982. The pollution potential of sanitary landfill. Effects of waste disposal on groundwater and surface water. INMS Publ. 139:125-135.

Tack, F.M., O.W.J.J. Callewaert, and M.G. Verloo. 1996. Metal solubility as a function of $\mathrm{pH}$ in a contaminated, dredged sediment affected by oxidation. Environ. Pollut. 91(2):199-208.

U.S. Department of Agriculture. 1990. Keys to soil taxonomy. 4th ed. SMSS Tech. Monogr. 6. Pocahontas Press, Blacksburg,VA.

Wang, W. 1992. Use of plants for the assessment of environmental contaminants. Rev. Environ. Contamin. Toxicol. 126:87-127.

Zhang, F., V. Römheld, and H. Marschner. 1991. Release of zinc mobilizing root exudate in different plant species as affected by zinc nutritional status. J. Plant Nutr. 14:675-686. 